large randomised cardiovascular trials, pharmacogenomics probably help to improve individual tailored therapy. Thus, I value the suggestion to assess the effect of angiotensinconverting enzyme genotype in further therapeutic studies on chronic obstructive pulmonary disease patients.

\section{S. Andreas}

Lungenfachklinik Immenhausen, Immenhausen, Germany.

\section{REFERENCES}

1 Andreas S, Anker SD, Scanlon PD, Somers VK. Neurohumoral activation as a link to systemic manifestation of chronic lung disease. Chest 2005; 128: 3618-3624.

2 Kanazawa H, Okamoto T, Hirata K, Yoshikawa J. Deletion polymorphisms in the angiotensin converting enzyme gene are associated with pulmonary hypertension evoked by exercise challenge in patients with chronic obstructive pulmonary disease. Am J Respir Crit Care Med 2000; 162: 1235-1238.

3 Kanazawa H, Hirata K, Yoshikawa J. Effects of captopril administration on pulmonary haemodynamics and tissue oxygenation during exercise in ACE gene subtypes in patients with COPD: a preliminary study. Thorax 2003; 58: 629-631.

4 Hopkinson NS, Nickol AH, Payne J, et al. Angiotensin converting enzyme genotype and strength in chronic obstructive pulmonary disease. Am J Respir Crit Care Med 2004; 170: 395-399.

5 Andreas S, Herrmann-Lingen C, Raupach T, et al. Angiotensin II blockers in obstructive pulmonary disease: a randomised controlled trial. Eur Respir J 2006; 27: 972-979.

6 Farber HW, Loscalzo J. Pulmonary arterial hypertension. N Engl J Med 2004; 351: 1655-1665.

DOI: $10.1183 / 09031936.06 .00079106$

\title{
Delirium induced by clarithromycin in a patient with community-acquired pneumonia
}

\section{To the Editors:}

We would like to describe the case of a patient who was treated with clarithromycin for community-acquired pneumonia (CAP). She presented with an episode of agitation and delirium while taking the clarithromycin, but this disappeared when the clarithromycin was stopped. This case is interesting because of the low frequency of symptoms of the central nervous system during the treatment.

The patient was a 63-yr-old female, with pathological history of arterial hypertension. She was treated with angiotensinconverting enzyme inhibitor and a pacemarker for atrial block and had no previous psychiatric history. The patient went to the emergency department in a poor general state; she had had a fever for 7 days and developed chills. Once at home, she was treated with paracetamol. A physical examination revealed a fever $\left(39^{\circ} \mathrm{C}\right)$, blood pressure of $120 / 60 \mathrm{mmHg}$ and heart frequency of 70 beats $\cdot \mathrm{min}^{-1}$. She had crepitations at the left hemithorax and cardiac arrhythmic tones without left ventricular failure. The abdomen was not painful and neurological examination was normal. The right thorax showed an alveolar pattern of the superior lobe in the left lung. The analytical results were as follows: glucose $104 \mathrm{mg} \cdot \mathrm{dL}^{-1}$; creatinin $0.91 \mathrm{mg} \cdot \mathrm{dL}^{-1}$; aspartate aminotransferase $118 \mathrm{UI} \cdot \mathrm{L}^{-1}$; sodium $140 \mathrm{mEq} \cdot \mathrm{L}^{-1}$; potassium $4.6 \mathrm{mEq} \cdot \mathrm{L}^{-1}$; leukocytes $6,200 \cdot \mu \mathrm{L}^{-1}$; haemoglobin $10.9 \mathrm{~g} \cdot \mathrm{dL}^{1}$; and platelets $265,000 \cdot \mu \mathrm{L}^{-1}$. The arterial blood gas results were: $\mathrm{pH} 7.57$; carbon dioxide tension $4.38 \mathrm{kPa}$; partial pressure of oxygen $10.37 \mathrm{kPa}$; and $\mathrm{HCO}_{3} 24 \mathrm{mEq} \cdot \mathrm{L}^{-1}$.

The ECG showed an atrial fibrillation. The diagnosis was severe CAP and the patient was treated with $2 \mathrm{~g}$ intravascular ceftriaxone every $24 \mathrm{~h}$ and $500 \mathrm{mg}$ intravascular clarithromycin every $12 \mathrm{~h}$. The patient also received sodium heparin for the atrial fibrillation. On the third day of treatment, the patient presented with an acute episode of agitation and delirium, which required administration of antipsychotics (haloperidol). A cranial computed tomography (CT) scan was carried out, which didn't show any alterations. The current authors suspected that the delirium was induced by clarithromycin as when treatment with the drug ceased the symptoms disappeared. The patient was observed by the psychiatric service and was diagnosed with delirium induced by clarithromycin in resolution phase. The patient presented with good evolution of CAP and outside hospital control she was asymptomatic.

Clarithromycin is an antibiotic belonging to the macrolide family with a structural ring of 14 atoms. The bacterial effect of the macrolides is due to the inhibition of protein synthesis, and the ability to administer it orally and intravascularly. Clarithromycin is metabolised by hepatic metabolism and the majority is eliminated biliary, in fomites and in a smaller portion in urine. It is active against Gram-positive cocci, Legionella and Chlamydia and is indicated in the treatment of severe CAP associated with cephalosporin (cefotaxime or ceftriaxone) [1].

Adverse effects of clarithromycin in the central nervous system include dizziness, ototoxicity and headaches, but delirium is very uncommon with few cases being reported in previous literature. In our case, it is obvious that there is a relationship between delirium and clarithromycin as the patient did not have any psychiatric history and delirium disappeared completely when the drug was removed. Other delirium causes were also excluded as the neurological exploration did 
not find any focus, the cranial CT scan was normal, and the patient was observed by the psychiatric service who diagnosed the case as delirium in resolution phase induced by clarithromycin, and delirium disappeared when the drug was removed.

In previous literature, some cases of hallucinations have been described in patients receiving clarithromycin with renal failure because of the possibility of the accumulating effect of the drug [2], but in the present patient the renal function was normal.

In other cases, effects in the central nervous system caused by clarithromycin appeared when the patient was taking fluoxetine at the same time. There is a possible interaction of the macrolide with the cytochrome P450 [3], which increases levels of fluoxetine, although other studies have attributed the appearance of delirium in these patients to the direct effect of clarithromycin only.

Clarithromycin, used in the treatment of the Mycobacterium avium complex $\left(1,000 \mathrm{mg} \cdot \mathrm{day}^{-1}\right)$, was responsible for the appearance of mania in two patients with AIDS [4] and in a group of elderly patients without HIV [5] who presented with confusion and insomnia. In all cases, the symptoms disappeared when treatment with the drug ceased.

Delirium induced by clarithromycin is an extremely uncommon adverse effect, but doctors have to know about this if they use this drug, because the delirium disappears when clarithromycin is removed from treatment.

\section{Vicente de Vera*, M. García\#, R. Pifarre Teixido ${ }^{\natural}$ and F. Barbe}

*Internal Medicine, and "Pneumology Section, University Hospital Arnau de Vilanova, and ${ }^{\#}$ CAP Ferran, Lleida, Spain.

\section{REFERENCES}

1 Niederman MS, Mandell LA, Anzuelto A, et al. Guidelines for the management of adults with community-acquired pneumonia. Diagnosis, assessment of severity, antimicrobial therapy, and prevention. Am J Respir Crit Care Med 2001; 163: 1730-1754.

2 Steinman MA, Steinman TI. Clarithromycin-associated visual hallucinations in a patient with chronic renal failure on continuous ambulatory peritoneal dialysis. Am J Kidney Dis 1996; 27: 143-146.

3 Pollak PT, Sketris IS, Mackenzie SL, Hewlett TJ. Delirium probably induced by clarithromycin in a patient receiving fluoxetine. Ann Pharmacother 1995; 29: 486-488.

4 Nightingale SA, Koster FT, Mertz GJ, Loss SD. Clarithromycin-induced mania in two patients with AIDS. Clin Infect Dis 1995; 20: 1563-1564.

5 Wallace RJ, Brown BA, Griffith DE. Drug intolerance to high-dose clarithromycin among elderly patients. Diagn Microbiol Infect Dis 1993; 16: 215-221.

DOI: 10.1183/09031936.06.00039006 